\title{
Influence of gender preference and sex composition of surviving children on childbearing intention among high fertility married women \\ in stable union in Malawi
}

Stephen Ayo Adebowale ${ }^{1,2}$, Martin Enoch Palamuleni ${ }^{1}$

1. Population Training and Research Unit, Faculty of Humanities and Social Sciences, North-West University, Mafikeng, South Africa

2. Department of Epidemiology and Medical Statistics, Faculty of Public Health, College of Medicine, University of Ibadan, Ibadan, Nigeria.

\section{Abstract}

Background: Child's gender preference (GP) frequently leads to high fertility which has adverse effect on family health. The link between women's fertility intention, GP and Living Children's Sex Composition (LCSC) as found in this study is less explored in Malawi.

Objectives: We examined the relationship between GP, LCSC and fertility intention.

Methods: This study utilized 2010 MDHS dataset and focused on married women aged 15-49 years ( $\mathrm{n}=1739)$ in stable unions who currently have at least 5 living children. Data was analyzed at bivariate and multivariate levels $(\alpha=0.05)$.

Results: About $39.7 \%$ of the women have GP and higher proportion (23.3\%) has preference for females. Age, region, Results: Auile, religion, residence and family panning programmes were significantly associated with fertility intenion Women who have GP and ame LCSC were 1.35 and 2.4 times significanty more likely to have intention to bear more chiphildren than those who have no GP and different sexes composition respectively. These odd ratios changed to 1.38 for GP and
2.44 for LCSC after adjusting for other socio-demographic variables.

Conclusions: We find that GP and LCSC significantly influence women's intention to bear more children. Women should stop childbearing after attaining their desired number irrespective of the LCSC.

Keywords: Fertility intention, Gender preference, Children sex composition, High fertility married women

DOI: http://dx.doi.org/10.4314/ahs.v15i1.21

Introduction

Malawi is a country of about 16.3 million people and the population growth rate is 2.8 percent.

Studies have shown tremendous improvement in the demographic indices of the country over the years. ${ }^{2,3}$

The infant and childhood mortality have reduced and there has been an improvement in contraceptive knowl-

\section{Corresponding author}

Stephen Adebowale Ayo

Population Training and Research Unit, Faculty of

Humanities and Social Sciences, North-West

University, Mafikeng, South Africa.

Department of Epidemiology and Medical Statistics,

Faculty of Public Health, College of Medicine,

University of Ibadan, Ibadan, Nigeria.

Email: Adehamilt2008@yahoo.com

Tel: +2348033565210 edge. Modern contraceptive utilization increased from 13\% in 1992 to $46.1 \%$ in $2010 .{ }^{2,3}$ The use of long acting methods, particularly sterilization, has consistently increased over years. The percentages of women who don't want to bear more children have also increased considerably from $26.6 \%$ in 1992 to $46.1 \%$ in 2010 . $^{2,3,4,5}$ Despite all these great demographic success, the Total Fertility Rate (TFR) only slightly reduced from 6.7 in 1992 to 5.7 in 2010 and Malawi is still recognized as one of the high fertility countries today. ${ }^{1}$ The slow pace of reduction in TFR has been a source of concern to fertility researchers and family planning programmer within and outside the country. In their search to identify the factors responsible for the high fertility in $\mathrm{Ma}$ lawi, numerous studies have been conducted across the country but only few have included gender preference and sex composition of the living children particularly among high fertility women as part of their key variables as evidenced in the current study.

Our study focused on high fertility women in stable union who either have intention to limit or postpone childbearing and also included women who do not want any more children. High fertility in this context means fertility women should have intention for more children having more than four surviving children. Also, women bearing in mind of its health and socio-economic impliwho have married only once in their life-time were re- cations particularly, in a country where majority of its garded as being in stable union. In a society where fertil- population lives in the rural area and earn below a dollar ity reduction campaign has a strong base and adherence per day. ${ }^{1}$ The consequence of high fertility on famito the themes of Programme of Action of 1994 Inter- ly as shown in appendix 1 includes: family's income national Conference on Population and Development, threatened, overstretch of family resources, care for the women who already have more than four surviving children and their education compromised, high morchildren should not have intention to bear more chil- bidity and mortality among under-five children in the dren. The restriction to highly fertile women was in family, mothers malnourished and health threatened, response to consistent reporting of four children on fathers health and labour activities threatened and povaverage as ideal number of children by Malawian wom- erty swells up. Small family size may increase the socioen..$^{2,3,5}$ In addition, to ascertain the reasons why high economic success position of the family in the society.

\section{Appendix 1: Model for Implication of high fertility on family}

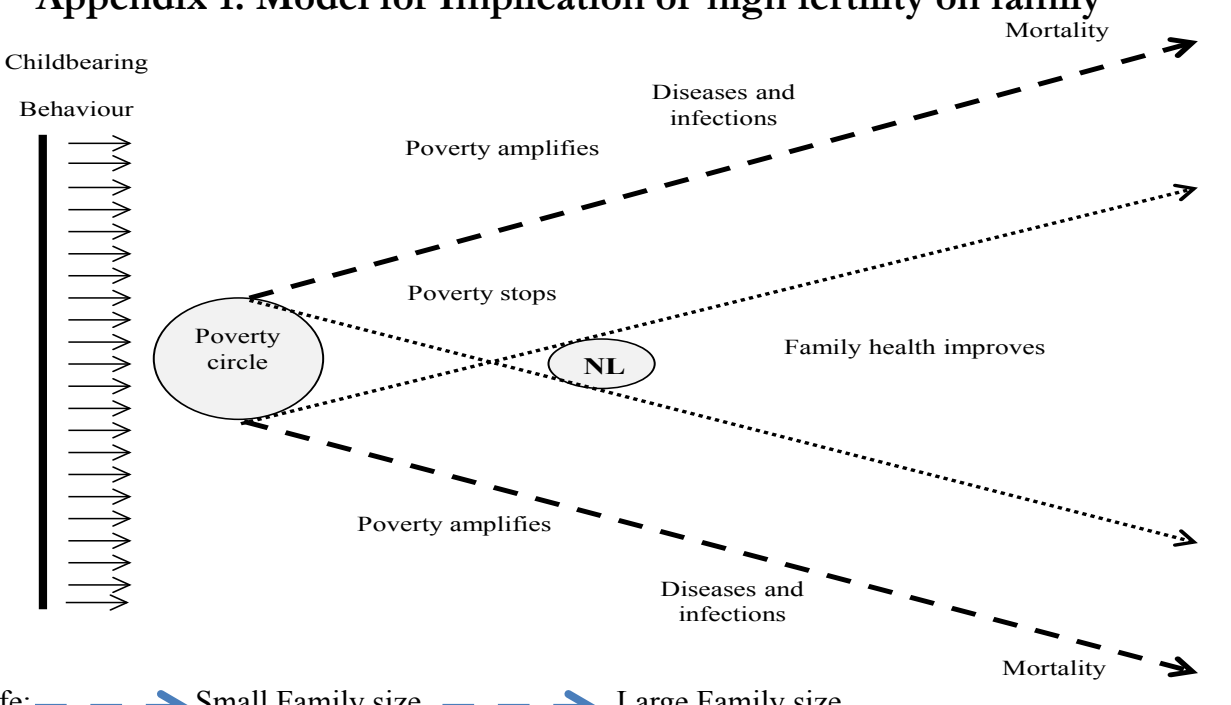

NL: New Life; $-\quad-\rightarrow$ Small Family size $-\boldsymbol{-} \rightarrow$ Large Family size

Source: Adebowale, 2011

In this study, we have chosen two key independent var- children until they are satisfied with their desired sex iables to explore their relationship with childbearing in- composition..$^{10,11}$ tention. These variables are; gender preference and sex composition of the surviving children. Gender preference is a social menace which has lasted too long in developing in developing countries and has attracted a lot of attention in the literature ${ }^{6,7,8}$ after the Cairo International Conference on Population and Development in 1994. In traditional culture, bearing many children was desired by couples, the belief among couples then was that children provide source of support at old age. But in modern world, having too many children is beginning to fade away because children are more appreciated today for social and psychological reasons. Strong child's gender preference is still common, even within segment of modern societies where such is least expected. ${ }^{9}$ In its context, issues associated with gender preference have presented researchers with several questions that have implications for public policies and programs. For instance, gender preference may be a direct contributing factor to high fertility, it shortens birth intervals, increases births frequency ${ }^{8}$ and some families stop having
In sub-Saharan Africa, considerable levels of gender preference in favour of sons have been reported in previous studies. ${ }^{6,12}$ This is because the expectation of parents is that male children add to family affluence, continue the family lineage, perform important religious roles and defend or exercise the family's power, while daughters sap the family resources and are married away to a different family. ${ }^{13,6,12}$ However, in families, there seems to be a consistent tendency for having at least one child of each sex often referred to as preference for gender mix. Gender preferences may have substantial implications for a couple's fertility behaviour. Unfortunately, there is only limited empirical research investigating this subject in Malawi. Our study was therefore designed to fill the gap.

The objectives of this study were to: explore the link between gender preference and fertility intention, ex-

African Health Sciences Vol 15 Issue 1, March 2015 
amine the relationship between fertility intention and was the 2008 Malawi PHC, which was provided by the sex composition of the surviving children and finally to National Statistical Office.

identify socio-demographic variables that are related to; gender preference, sex composition of the living children and intention to bear more children. To achieve the objectives, these questions are to be answered: Does child gender preference promote intention of high fertility women to bear more children? Does the sex composition of the living children advance intention of high fertility women to bear more children? What are the socio- demographic factors associated with fertility intention among high fertility women? Why should women who already have at least five surviving children intend to bear more? We hope that the study outcome will assist policy makers in their pursuit for gender equality and fertility reduction in Malawi.

\section{Methods}

Study area:

Malawi is a country in sub-saharan African located south of the equator. The country is divided into three regions: the Northern, Central, and Southern Regions. There are 28 districts in the country. 6 districts are in the Northern Region, 9 are in the Central Region, and 13 are in the Southern Region. Administratively, the districts are subdivided into traditional authorities (TAs), presided over by chiefs. Each TA is composed of villages, which are the smallest administrative units, and the villages are presided over by village head. The 2008 Population and Housing Census (PHC) found the population to be 13.1 million but the projected population as estimated by Population Reference Bureau in 2013 was 16.3 million. Malawi adopted a National Population Policy in 1994, which was designed to reduce population growth to a level compatible with Malawi's social and economic goals. ${ }^{14}$ One of the policy's objectives was to improve family planning and health care programmes.

\section{Study Design:}

The design for the study was cross-sectional and 2010 The dependent variable:

Malawian Demographic Health and Survey (MDHS) The dependent variable was fertility intention. In the was used. ${ }^{2}$ During the data collection exercise by the primary user, a multi-stage cluster sampling method was adopted. The sample was designed to provide population and health indicator estimates at the national, regional, and district levels. The sample design allowed for specific indicators, such as contraceptive use, to be calculated for each of the country's 3 regions and 28 districts. The sampling frame used for the 2010 MDHS
The districts in Malawi are subdivided into Traditional 2008 PHC, the TAs were subdivided into enumeration areas (EAs), also referred to as clusters, where each EA as a whole was classified as urban or rural. The 2010 MDHS sample was selected using a stratified, two-stage cluster design, with EAs being the sampling units for the first stage. This included 849 clusters: 158 in urban areas and 691 in rural areas. The list of households served as a sampling frame for selection of houserequired per district to provide an acceptable level of precision for the indicators measured in the survey. A representative sample of 27,345 households was selected for the survey. Detailed information about the data

\section{Data extraction:}

Data was downloaded from the Measure DHS website after the approval for use was granted by the data orig-

The sample size:

At the time of the survey, 23,020 women aged 15-49 fertility in this context means having at least five living

\section{The exclusion criteria:}

The study excluded women who; were currently un(nared), had married more than once (not in stable union), had less than five living children, were menopausal, never had sexual intercourse and those who were sterilized or declared infecund. original questionnaire used for the survey, a question was asked from the women on their fertility intention. The possible options are; have another, undecided, want no more, sterilized, declared infecund and never had sex. Based on the exclusion criteria set for this study, we focused on women who responded that they still want to bear more children and those who said they don't want any more. Therefore, a woman fertility intention Authorities (TAs) and each TA is composed of villages which are the smallest administrative units. During the holds. A minimum sample size of 950 households was collection procedures is available in the 2010 MDHS. ${ }^{2}$ were interviewed. This study utilized 1739 high fertility women based on the exclusion criteria below. High married (never married, cohabiting, widowed, divorced, defined for this study means that she either intends to bear more children or wants no more.

\section{The key independent variables of interest:}

The key independent variables were Gender Preference (GP) and Sex Composition of the Living Children (SCLC). Gender preference was self generated as proxy from the information on ideal number of sons and ideal number of daughters. Women who reported higher number of males than females as ideal number of children were regarded as having preference for males while those who reported higher number of females were considered as having preference for females. But, those who reported the same number of children or who verbally said that either of the sex or accept God's decision as their ideal number of sex were considered as not having preference. Also, the sex composition of the living children was generated from the information on number of living daughters and living sons.

The SCLC was generated as a proxy from the information on the number of living daughters and living sons. At the time of the survey, information was sought on the number of living daughters and living sons. It is possible that the living children of a woman are; Case 1: either all males or all females. Case 2: sex mix i.e some are males and others are females. Case 1 was categorized as "same sex". This is a situation where all the living children in the family are of the same sex and case 2 was regarded as "different sexes". This means that the sex composition of the family contains at least a male and at least a female.

\section{ent variables:}

Other independent variables were current age of the women, religion, region, wealth quintile, place of res-

The dependent variable has two categories; either woman wants no more or she wants more children. We The equations for the models are represented thus;

$$
\log \left\{\frac{\varphi_{1}}{1-\varphi_{1}}\right\}=B_{01}+B_{41} G P
$$

$\log \left\{\frac{\varphi_{2}}{1-\varphi_{2}}\right\}=\beta_{02}+\beta_{12}$ SCLC

$\log \left\{\frac{\varphi_{3}}{1-\phi_{1}}\right\}=\beta_{0}+\beta_{11} \mathrm{GP}+\beta_{12} \operatorname{SCLC}$

$$
\log \left\{\frac{\varphi_{4}}{1-\varphi_{2}}\right\}=\beta_{04}+\beta_{14} \mathrm{GP}+\beta_{12} \text { SCLC }+\sum_{\mathrm{i}=1}^{\mathrm{n}} \beta_{2} \text {,variable }
$$

African Health Sciences Vol 15 Issue 1, March 2015 
thus, the classification (woman wants more $=1$ or 0 if ethical approval was obtained from National Health otherwise). Therefore, the dependent variable is dichot- Sciences Research Committee functioning under the

omous and as such we used logistic regression model Ministry of Health, Malawi. An informed consent was for the multivariate analysis. At this stage, three models obtained from all the study participants after describing were generated. In the first model, the two key inde- to them all the issues related to the study in details at the pendent variables; gender preference and sex compo- point of data collection. Eligible respondents who did sition were introduced into the equation independently not want to partake in the study were excluded from the to see their influence on fertility intention without in- survey. Each consented participant was made to sign teracting with any other variables. In model 2 , the two appropriate agreement form before the interview.

variables were introduced into the equation jointly in Formal online approval was granted by the mMeasure order to see their interaction effect on the dependent dhs DHS before the utilization of the $2010 \mathrm{MDHS}$ davariable. In model 3 , other socio-demographic variables taset for our study.

were included in the equation as control.

\section{Ethical Clearance:}

\section{Results}

\section{Univariate:}

At the time of data collection by the data originator, In figure 1 , the data show that $76.0 \%$ of the currently married women

Figure 1: Pie chart of the percentage distribution of currently married high fertility women in Malawi according to number of union

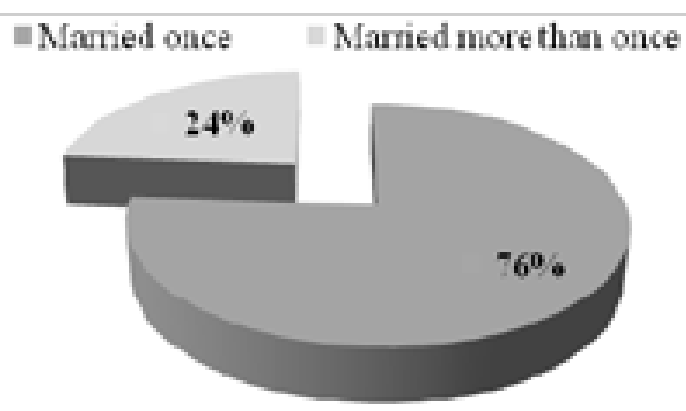

Figure 2: Data plot of the percentage distribution of currently married high fertility women in stable union in Malawi by fertility intention according to their current age

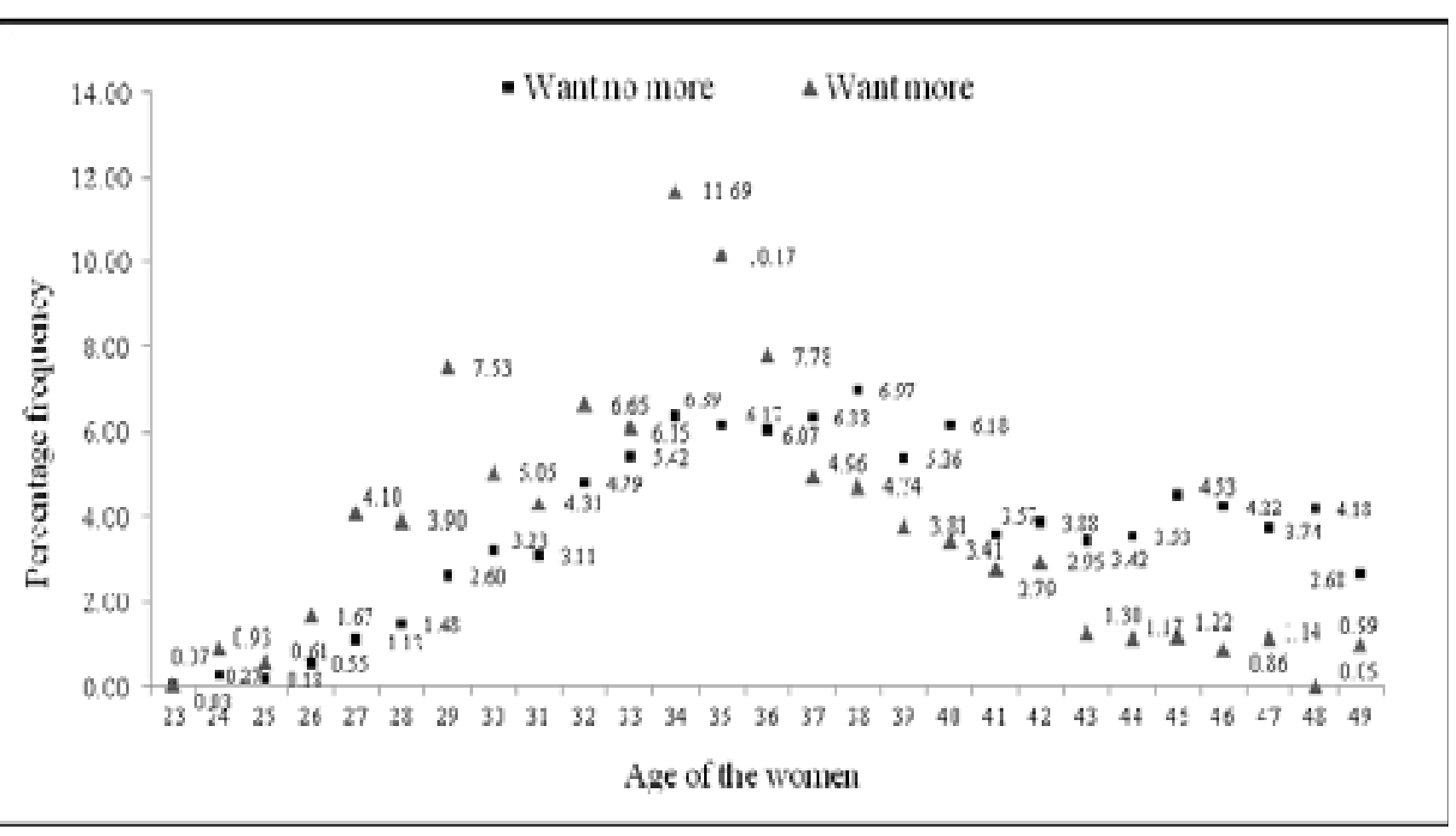

ried once. Thus, the remaining part of the analysis focused on these set of women.

As shown in the data plot in figure 2 , women who wanted more children were more than those who did not want any more at ages less than 36 years whereas those who don't want any more children dominate the later part of childbearing years.

Figure 3: percentage distribution of currently married high fertility women in Malawi according to their Ethnicity

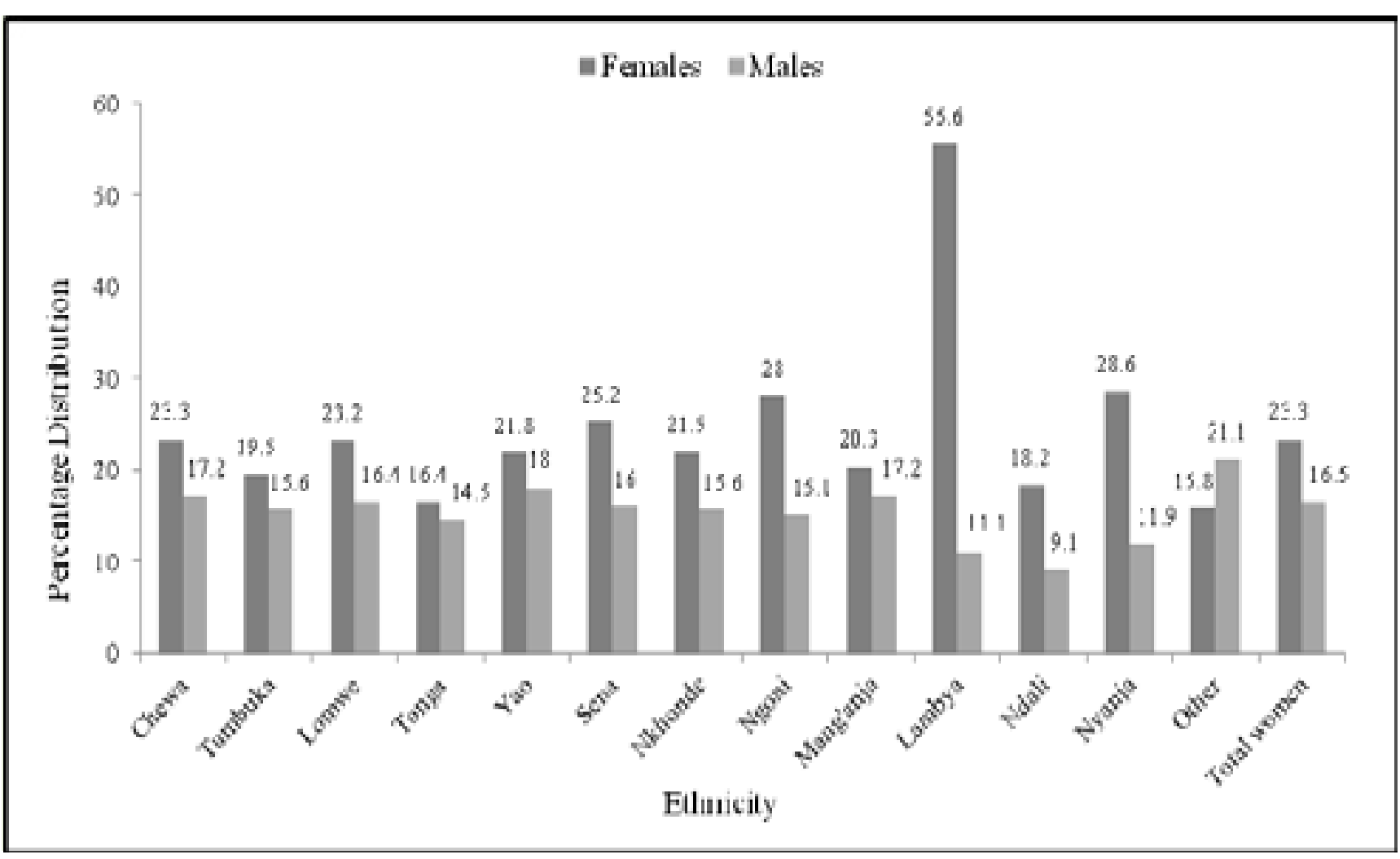

\section{Bivariate:}

The data is evidenced that about $16 \%$ of the women studied have intention to bear more children while $18.4 \%$ of women who have gender preference intended to bear more children, $14.4 \%$ of those who don't have gender preference have intention to have more children. Higher proportion of women whose childrens' sex composition are the same (30.4\%) wanted more children as against $15.3 \%$ of families where the sex composition of their children was gender mix. The Central Region of Malawi has least proportion of its women $(12.6 \%)$ having intention to bear more children compared with those in the North (16.7\%) and South $(19.2 \%)$. Clear rural urban differential existed in the percentage of women who intend to bear more children with higher proportion of women residing in the rural areas (16.5) wanting to bear more children than women in the urban $(9.7 \%)$. The percentage of women who wanted more children reduces consistently with increasing level of women empowerment, reducing from $17.9 \%$ among those who are not empowered to $9.7 \%$ among the highly empowered.

The data further revealed that $13.8 \%$ of women who recently heard about family planning messages through media (radio, television, newspaper) signified intention to bear more children compared to $19.2 \%$ of their counterparts who have not heard of such messages. According to religion, higher proportions of the Muslims $(24.7 \%)$ want more children than any Christian religious group. The percentage of women who wanted more children reduces consistently with increasing marital duration.

African Health Sciences Vol 15 Issue 1, March 2015 
Table 1: Percentage distribution of currently married high fertility women in Malawi according to their fertility intention

Protestants: CCAP/Anglican/Seven day/Baptist; NOLC: Number of living children

\begin{tabular}{|c|c|}
\hline Background & Fertility Intention \\
\hline Characteristics & \\
\hline Total & 16.0 \\
\hline GenderPreference & \\
\hline $\begin{array}{l}\text { Yes } \\
\text { No }\end{array}$ & 18.4 \\
\hline $\begin{array}{l}\text { No } \\
\text { Childrensexcomposition }\end{array}$ & \\
\hline $\begin{array}{l}\text { Same sex } \\
\text { Different sexes }\end{array}$ & 30.4 \\
\hline $\begin{array}{l}\text { Different sexes } \\
\text { Region }\end{array}$ & 15.3 \\
\hline Northern & 16.7 \\
\hline $\begin{array}{l}\text { Central } \\
\text { SOnther }\end{array}$ & 12.6 \\
\hline $\begin{array}{l}\text { Southern } \\
\text { Residence }\end{array}$ & 19.2 \\
\hline Urban & \\
\hline $\begin{array}{l}\text { Rural } \\
\text { WealthOuintile }\end{array}$ & 16.5 \\
\hline $\begin{array}{l}\text { WealthQuintile } \\
\text { Poorest }\end{array}$ & \\
\hline $\begin{array}{l}\text { Pooorest } \\
\text { Poorer }\end{array}$ & 18.8 \\
\hline Middle & 13.5 \\
\hline Richer & 16.7 \\
\hline $\begin{array}{l}\text { Richest } \\
\text { Womemempowerment }\end{array}$ & 7.7 \\
\hline Not empowered & 17.9 \\
\hline Poorly & 16.9 \\
\hline $\begin{array}{l}\text { Averagely } \\
\text { Hiobly }\end{array}$ & $\begin{array}{l}13.1 \\
07\end{array}$ \\
\hline $\begin{array}{l}\text { Highly } \\
\text { Agegroup }\end{array}$ & 9.7 \\
\hline$\frac{15-34}{15}$ & 25.7 \\
\hline $35+$ & 11.2 \\
\hline $\begin{array}{l}\text { HeardaboutFamilyPlanni } \\
\text { No }\end{array}$ & $\frac{\text { grecently }}{19.2}$ \\
\hline $\begin{array}{l}\text { No } \\
\text { Yes }\end{array}$ & $\begin{array}{l}19.2 \\
13.8\end{array}$ \\
\hline Religion & \\
\hline $\begin{array}{l}\text { Catholic } \\
\text { Protestants }\end{array}$ & 15.6 \\
\hline $\begin{array}{l}\text { Protestants } \\
\text { Other Christians }\end{array}$ & 12.0 \\
\hline $\begin{array}{l}\text { Other Christians } \\
\text { Muslims }\end{array}$ & $\begin{array}{l}15.4 \\
24.7\end{array}$ \\
\hline $\begin{array}{l}\text { Others } \\
\text { Othe }\end{array}$ & 21.4 \\
\hline $\begin{array}{l}\text { Education } \\
\text { Edur }\end{array}$ & \\
\hline & 17.5 \\
\hline Primary & 15.5 \\
\hline $\begin{array}{l}\text { Secondary and above } \\
\text { Maritalduration }\end{array}$ & 9.8 \\
\hline M-9 $\frac{\text { Maritalduration }}{5}$ & \\
\hline $10-14$ & 26.4 \\
\hline $15-19$ & 21.8 \\
\hline
\end{tabular}

\begin{tabular}{|c|c|c|c|c|}
\hline $\begin{array}{l}\text { Total } \\
\text { Women }\end{array}$ & $\chi^{2}$-value & $\begin{array}{l}\text { p- } \\
\text { value }\end{array}$ & $\begin{array}{l}\text { Mean } \\
\text { NOLC }\end{array}$ & $\begin{array}{l}p^{-}- \\
\text {value }\end{array}$ \\
\hline 1739 & 4.889 & 0.027 & $6.03 \pm 1.264$ & 0.159 \\
\hline $\begin{array}{c}691 \\
1048\end{array}$ & & & $\begin{array}{l}6.06 \pm 1.243 \\
5.98 \pm 1.294\end{array}$ & \\
\hline & 12.884 & $<0.001$ & $5.24 \pm 0.478$ & $<0.001$ \\
\hline 1660 & 12.227 & 0.002 & $6.07 \pm 1.278$ & 0.254 \\
\hline $\begin{array}{l}245 \\
760 \\
734\end{array}$ & & & $\begin{array}{l}5.93 \pm 1.155 \\
6.08 \pm 1.307 \\
6.01 \pm 1.252\end{array}$ & \\
\hline 143 & 4.528 & 0.033 & $6.03 \pm 1.324$ & 0.950 \\
\hline & 24.452 & $<0.001$ & $6.03 \pm 1.259$ & 0.025 \\
\hline $\begin{array}{l}316 \\
373 \\
385 \\
407\end{array}$ & & & $\begin{array}{l}5.90 \pm 1.115 \\
6.04 \pm 1.298 \\
6.20 \pm 1.331 \\
5.98 \pm 1.281\end{array}$ & \\
\hline 25 & 8.243 & 0.041 & $5.98 \pm 1.237$ & 0.032 \\
\hline $\begin{array}{l}736 \\
445 \\
413 \\
113\end{array}$ & & & $\begin{array}{l}6.03 \pm 1.262 \\
6.15 \pm 1.330 \\
5.89 \pm 1.205 \\
6.00 \pm 1.153\end{array}$ & \\
\hline & 60.074 & $<0.001$ & & $<0.001$ \\
\hline $\begin{array}{r}572 \\
1167\end{array}$ & & & $\begin{array}{l}5.37 \pm 0.626 \\
6.35 \pm 1.366\end{array}$ & \\
\hline $\begin{array}{l}698 \\
1041\end{array}$ & 8.904 & 0.003 & $6.07 \pm 1.318$ & 0.256 \\
\hline $\begin{array}{c}379 \\
415 \\
681 \\
250 \\
14\end{array}$ & 19.457 & $<0.001$ & $\begin{array}{l}6.01 \pm 1.335 \\
5.92 \pm 1.228 \\
5.98 \pm 1.176 \\
6.36 \pm 1.392 \\
6.03 \pm 1.293\end{array}$ & $<0.001$ \\
\hline $\begin{array}{c}544 \\
1133 \\
62\end{array}$ & 2.778 & 0.249 & $\begin{array}{l}6.22 \pm 1.335 \\
5.97 \pm 1.232 \\
540+0.815\end{array}$ & $<0.001$ \\
\hline $\begin{array}{l}21 \\
273 \\
587 \\
859\end{array}$ & 79.250 & $<0.001$ & $\begin{array}{l}5.02 \pm 0.137 \\
5.22 \pm 0.531 \\
5.60 \pm 0.799 \\
6.60 \pm 1.423\end{array}$ & $<0.001$ \\
\hline
\end{tabular}

Multivariate:

ligion and marital duration. Women who reside in the It is worth noting that limiting the independent vari- Central Region were 0.65 (C.I $=0.475-0.891 ; p=0.007$ ) ables to gender preference and sex composition, and less likely to intend to have more children than those in controlling for other variables have only slight effect on the Southern Region. Being in the poorest wealth quinthe odds ratios of gender preference and sex composi- tile encourages intention to bear more children, these tion. In this case, women who have GP and same sex women were 2.822(C.I=1.523-5.228; $\mathrm{p}=0.001)$ more composition were $1.38(\mathrm{C} . \mathrm{I}=1.046-1.822 ; \mathrm{p}=0.023)$ and likely have intention to have more children than those 2.1(C.I $=1.238-3.620 ; \mathrm{p}=0.006)$ times more likely to have in the richest wealth quintile. The data further show that intention to bear more children than those who have no the higher the level of women empowerment the lower GP and different sexes composition respectively. the likelihood of intention to bear more children. Sim-

ilar pattern exists for marital duration. The likelihood Other identified predictors of intention to bear more of intention to bear more children was higher among children among high fertility women in Malawi were Muslims ( $O R=1.855$; C.I=1.183-2.910; $\mathrm{p}=0.007$ ) than region, wealth quintile, women empowerment, age, re- Christians.

Table 2: Logistic regression of currently married high fertility women in Malawi according to their fertility intention

\begin{tabular}{|c|c|c|c|c|c|c|}
\hline 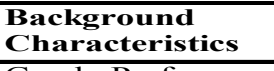 & $\begin{array}{l}\frac{\text { Moden I }}{\text { UOR }} \\
\end{array}$ & $95 \%$ CIUOR & $\begin{array}{ll}\text { MOde } 2 \\
A O R\end{array}$ & $95 \%$ CIAOR & $\begin{array}{l}\text { MS\% AOR } \\
95 \% \text { BOR }\end{array}$ & $95 \%$ CIAOR \\
\hline $\begin{array}{l}\text { GenderPreference } \\
\text { Preference } \\
\text { No Preference } \\
\text { G Prese }\end{array}$ & ${ }_{1}^{1.345^{* * * *}}$ & $1.038-1.742$ & $1.359 * * * *$ & $1.048-1.762$ & $1_{1}^{1.380 * *}$ & $1.046-1.822$ \\
\hline $\begin{array}{l}\text { Sexcomposition } \\
\text { Same sex } \\
\text { Different sexes }\end{array}$ & $2.438^{*}$ & $1.486-4.001$ & $2.477 *$ & $1.508-4.071$ & $2.117^{* * *}$ & $1.238-3.620$ \\
\hline $\begin{array}{l}\text { Region } \\
\text { Northern } \\
\text { Central } \\
\text { Southern }\end{array}$ & & & & & $\begin{array}{l}1.336 \\
0.650^{* *} \\
1\end{array}$ & $\begin{array}{l}0.871-2.049 \\
0.475-0.891\end{array}$ \\
\hline $\begin{array}{l}\text { Residence } \\
\text { Urban } \\
\text { Rural }\end{array}$ & & & & & $\begin{array}{l}0.709 \\
1\end{array}$ & $0.367-1.371$ \\
\hline $\begin{array}{l}\text { WealthQuintile } \\
\text { Poorest } \\
\text { Poorer }\end{array}$ & & & & & $\begin{array}{l}2.822 * * \\
2.372 * *\end{array}$ & $\begin{array}{l}1.523-5.228 \\
1295-4.343\end{array}$ \\
\hline $\begin{array}{l}\text { Poorer } \\
\text { Middle } \\
\text { Richer } \\
\text { Richest }\end{array}$ & & & & & $\begin{array}{l}2.372 \text { 2** } \\
2.4415^{* * *} \\
1\end{array}$ & $\begin{array}{l}1.295-4.343 \\
0.900-3.010 \\
1.362-4.284\end{array}$ \\
\hline $\begin{array}{l}\text { Women empowerment } \\
\text { Not empowered }\end{array}$ & & & & & $2.557^{* *}$ & $1.278-5.117$ \\
\hline $\begin{array}{l}\text { Poorly } \\
\text { Averagely } \\
\text { Highly }\end{array}$ & & & & & $\begin{array}{l}2.2614^{1 * *} \\
1.844 \\
1\end{array}$ & $\begin{array}{l}1.109-4.607 \\
0.892-3.809\end{array}$ \\
\hline $\begin{array}{l}\text { Agegroup } \\
155+34 \\
35+\end{array}$ & & & & & ${ }_{1}^{1.601 * * *}$ & $1.053-2.169$ \\
\hline $\begin{array}{l}\text { HeardaboutFamily } \\
\text { No Yes } \\
\text { Religion } \\
\text { ClAP }\end{array}$ & Planningrec & ntly & & & ${ }_{1}^{1.261}$ & $0.947-1.680$ \\
\hline $\begin{array}{l}\text { Other Chngilian/s } \\
\text { Muslims }\end{array}$ & ven day/Ba & & & & $\begin{array}{l}0.772 \\
0.945\end{array}$ & $\begin{array}{l}0.499-1.195 \\
0.694-1.378\end{array}$ \\
\hline $\begin{array}{l}\text { Muslims } \\
\text { Others }\end{array}$ & & & & & $\begin{array}{l}1.855^{* * *} \\
1.94\end{array}$ & $\begin{array}{l}.649-1.378 \\
1.183-2.910\end{array}$ \\
\hline $\begin{array}{l}\text { Catholic } \\
\text { Maritalduration } \\
509\end{array}$ & & & & & & $0.173-4.522$ \\
\hline $\begin{array}{l}\text { 10-14 } \\
15-19\end{array}$ & & & & & $\begin{array}{l}3.708^{* * *} \\
2.663^{*} \\
2.663^{*}\end{array}$ & $\begin{array}{l}1.177-11.68 \\
1.628-4.357 \\
1.815-3.820\end{array}$ \\
\hline $20+$ & & & & & \multicolumn{2}{|l|}{1} \\
\hline-2 Log likelihood & & & 1510.715 & & 1330.071 & \\
\hline
\end{tabular}

"Significant at 0.1\%; **Significant at 1\%; *** significant at 5\%; UOR: Unadjusted Odds Ratio; AOR: Adjusted
CIUOR: Confidence Interval of Unadjusted Odds Ratio; CIAOR: Confidence Interval of Adjusted Odds Ratio

\section{Discussion} The study explored the effects of gender preference males; it is worth noting that in the current investigaand sex composition of living children on fertility in- tion, majority of the women studied have preference for tention among high fertility married women in stable females. The finding is in contrary to previous studies unions in Malawi. High fertility constitutes threat to conducted in sub-Saharan Africa and other countries maternal and child health. It also has tremendous im- where male preference have been widely reported. ${ }^{16,17,18}$ plication on women's development and empowerment. In a patriarchal setting, son preference is generally In some families, couples may have decided shortly viewed as a socially unwavering prejudice. Here, couafter marriage the number of children they would like ples desire to raise a child who has characteristics that to bear in their life time and this is achievable in the are culturally accepted which are linked with male sex. modern society with the existence of different choices This preference often influences behavior and may reof fertility control measures. But, couple's intention on sult in gender discrimination that negatively affect girls' the number of children they desire might change if all and women's welfare, health and survival. ${ }^{19}$ The preftheir live born children are of the same sex. The link be- erence for female children in Malawi across ethnic tween women's intention to bear more children, gender groups is not surprising and could be attributed preference and sex composition of the living children to the fact that some parts of Malawi are matrilineal in Malawi as examined in the current study has not been which means they trace their lineage to their mother. In comprehensively established in the literature. this culture, the men villages and the mother's brother (atsibweni) often plays 
important role in the family. ${ }^{20,21}$ For instance, among the Chewa's, the largest ethnic group in Malawi, the inherit from their mother's side and daughters occupy important position in the society. They are often consulted in the society for important decision. Our result is similar to the outcome of Karsten and Hans-Peter, where preference for females was found in the Czech Republic, Lithuania, and Portugal and it was argued that cultural factors are important for gender preferences. ${ }^{22}$

About one-sixth and one-fifth of the women studied and those who have gender preference have intention to bear more children respectively. Considering the health and socioeconomic implication of high fertility, the prevalence of fertility intention among women who already have more than four living children can be considered as high. One may find it difficult to disentangle factors surrounding such intention among the women, but our study clearly revealed that gender preference and sex composition of the living children are important factors to reckon with. The result of multivariate is evidenced that strong influence of gender preference and sex composition of the living children is found when other socio-demographic factors were used as control. As shown in the previous paragraphs, gender preference is still widely practiced in Malawi and as such, women might decide to continue to bear more children until they have their desired sex or sex composition. Other studies in similar settings corroborate ou findings. 23,24

For instance, a study conducted in Pakistan revealed that the sex of surviving children was strongly correlated with subsequent fertility and contraceptive behaviour. $^{24}$

Although, slight variation exists between the regions in Malawi with respect to intention to bear more children, women living in the Central Region were less likely to signify intention for more children than any other regions across the country.

Our study further shows that highly empowered women were less likely to have intention to have more children than those women who were either less empowered or not empowered. In Malawi's context, those who are less empowered see childbearing as contribution to the society, the more children they have the more they have achieved. The finding is expected as highly empowered women are often more likely to have con- trol over some household decisions including intenfertility. Researchers have explored the association between women's empowerment, contraceptive use and fertility. Findings from these studies reveal that women's empowerment is significantly related to modern contraceptive use and lowers fertility. ${ }^{25,26,27,28}$ Consisten evidence from previous studies have also revealed that women's empowerment is a link through which education influences fertility. 29,30

Other identified predictors of fertility intention in this study were; religion, marital duration and wealth quintile. For example, the likelyhood of intention to bea more children was higher among Muslims than Christians. Also, differential existed between the Muslim and Catholic women as Muslim women were about twice more likely to show intention to bear more children than Catholic women. This finding is in agreement with the outcome of previous studies conducted in Malawi and other parts of sub-Saharan Africa where Muslim women consistently have higher fertility than thei Christian counterparts. ${ }^{4,5,31}$ Also, in selected settings in four Asian countries, it was found that Muslim wives usually have more children, are more likely to desire additional children, and are less likely to be using contraception when they desire no more children. ${ }^{32}$

It is striking that the likelihood of women in the poor est wealth quintile who wanted more children after having at least five children was approximately three times of those in the richest wealth quintile. In Malawi context, this is expected as most of the poorest women are less educated and live in the rural areas where family planning information is limited and at times not accessible. This argument was the reason for high fertility among women in Africa as found in a study by Andreea et al., where after adjustment for fertility intention, women in the richest wealth quintile were more likely than those in the poorest quintile to practice long-term contraception. ${ }^{33,34}$ Cultural practices that are challenges to achieving reproductive health goals including child preference are more common among poorest women than the richest. Further research most especially qualitative study may be needed to identify the reasons while poorest women have more interest on childbearing in Malawi. This will assist family planning experts in thei quest for addressing issues of fertility reduction in $\mathrm{Ma}$ lawi and other countries of similar demographic characteristics.
We focused on 1,739 women (based on the exclusion criteria set for this study) from the 23,020 women in cluded in the original sample. Therefore, the findings from this study might be incomparable to fertility intention expected among all Malawian women. In addition, secondary data source was used for this study, as such; problems associated with the use of secondary data cannot be completely overruled from the results of our analysis. For instance, some contextual variables were not captured in the original sample thus limiting their inclusion in our analysis. Also, gender preference as one of the key variables analyzed in this study was created as a proxy using information on ideal number of males and females children reported by the women included in this study. There might be possibility of slight disparity between our finding and the true situation if question on gender preference was originally included in the questionnaire used for the surver.

\section{Conclusion}

Child's gender preference is still common in Malawi and higher preference for female child was reported. Gender preference and same sex composition were the major reasons responsible for women's intention to bear more children after having five living children. Al though, numerous factors were found to be associated with fertility intention among the women studied but the identified predictors were gender preference, sex composition of the living children, region, age, marital duration, women empowerment and religion. Strategies to eradicate child's gender preference should be developed in Malawi. This must be exercised within the framework of the sexual and reproductive rights of women.

The existing policy in Malawi says that couples should decide on the number of children they want, however, the available statistics indicate that the ideal number of children a woman should bear is four; ${ }^{2,3,4,5}$ it is therefore tempting to argue that the family planning policy makers should advocate that each woman must not have more than four children. In addition, the family planning programme should assist couples or individual women to achieve this demographic goal by encouraging all women who have four living children to start using long acting/permanent method irrespective of the gender composition of the living children or woman's age. Since religion is one of the identified predic- ors of childbearing intention found in this study, enguch institutions as Muslim and Christian association of Malawi in population and reproductive health programs should be strengthened.

As found in this study, more women reported that they prefer female children to males. In African context, where most studies have reported son's preference, this finding seems to be striking; we therefore suggest qualitative research to explore reasons for such deviation in Malawi.

\section{Acknowledgements}

The authors are grateful to Macro-International U.S.A and National Population Commission for allowing us to use their data (NDHS, 2008) for this study.

\section{References:}

1. PRB. Population Reference Bureau. Word Population Data-sheet. 20132

2. National Statistical Office (NSO) and ICF Macro. Malawi Demographic and Health Survey 2010. Zomba Malawi, and Calverton, Maryland, USA: NSO and ICF Macro.

3. National Statistical Office (NSO) and ICF Macro. Malawi Demographic and Health Survey 1992. Zomba, Malawi, and Calverton, Maryland, USA: NSO and ICF Macro.

4. National Statistical Office (NSO) and ICF Macro. Malawi Demographic and Health Survey 2000. Zomba, Malawi, and Calverton, Maryland, USA: NSO and ICF Macro

5. National Statistical Office (NSO) and ICF Macro Malawi Demographic and Health Survey 2004. Zomba, Malawi, and Calverton, Maryland, USA: NSO and ICF Macro

6. Kana F. Variations in attitudinal gender preferences for children across 50 less-developed countries. Demographic Research: 2010; Vol. 23, Article 36 Descriptive Findings http:/ / www.demographic-research.org 1031 7. Perianayagam A. Gender preference, contraceptive use and fertility in India: regional and development influences. International Journal of Population Geography 2002; Vol.8,(1):49-67

8. Choe MK. Son preference, family building process and child mortality, in: UN Secretariat, ibid. 1998; pp. 208-222.

9. Higginson MT and Aarssen LW. Gender bias in off- 
spring preference: sons still a higher priority, but only in men-women prefer daughters. The open anthropology journal, 2011; (4):60-65.

10. Dalla ZG and Leone T. A gender preference measure: the sex ratio at last birth. Genus 2001; LVII(1):3357.

11. Clark SS. Child preference and sex composition of children: evidence from India. Demography 2000; 37(1):95-108.

12. Ndu AC and Uzochukwu BSU. Child gender preferences in an urban and rural community in Enugu, eastern Nigeria. Journal of College of Medicine 2011; Vol. 16 No 1, 2011

13. Biddlecom AE, Munthali A, Singh S, and Woog V. Adolescents' views of and preferences for sexual and reproductive health services in Burkina Faso, Ghana, Malawi and Uganda. Afr I Reprod Health 2007; 11(3): 99-100.

14. Office of the President and Cabinet (OPC) [Malawi]. The National HIV and AIDS Policy. Lilongwe, Malawi: Government of Malawi. 2003.

15. Measure DHS, ICF International, 11785 Beltsville Drive, Suite 300 Calverton, MD 20705 USA http:// www.measuredhs.com/

16. Obikeze, D. S. 1988. Son Preference among Nigerian Mothers: Its Demographic and Psycho-Social Implications. International Journal of Contemporary Sociology pg 55-63.

17. Adeleye OA and Okonkwo CA. Ideal Child Gender Preference in Men's Worldview and Their Knowledge of Related Maternal Mortality Indices in Ekiadolor, Southern Nigeria. Asian Journal of Medical Sciences 2010; 2(3): 146-151.

18. Chai BP and Nam-Hoon C. Consequences of Son Preference in a Low-Fertility Society: Imbalance of the Sex Ratio at Birth in Korea. Population and Development Review 1995; Vol. 21, No.1

19. Kua W and Vipan PR. Sex Preference for Children in Thailand and Some other South- East Asian Countries. Asia-Pacific Population Journal 1995; Vol. 10, No. (3):43-62

20. Karsten H, Hans-Peter K. Gender Preferences for Children in Europe: Empirical Results from 17 FFS Countries. Demographic Research 2000; Vol. 2 - Article 1

21. Berge E, Kambewa D, Munthali A, Wiig H. Lineage and Land Reforms in Malawi: Do Matrilineal and
Patrilineal Landholding Systems Represent a Problem for Land Reforms in Malawi? CLTS Working Papers: 19, 2013

22. Peters P.E. "Our daughters inherit our land, but our sons use their wives' fields": matrilineal-matrilocal land tenure and the New Land Policy in Malawi. J. East. Afr. Stud., 4 (1) (2010), pp. 179-199

23. Suet-ling P. Sex Preference and Fertility in Peninsular Malaysia. Studies in Family Planning. 1994; Vol. 25, No. 3

24. Hussain R, Fikree FF; Berendes HW. The role of son preference in reproductive behaviour in Pakistan Bull World Health Organ 2000; Vol.78 no.3

25. Woldemicael G. Women's Autonomy and Reproductive Preferences in Eritrea. J Biosoc Sci 2009;41(2):161181

26. Hindin MJ. Women's Autonomy, Women's Status and Fertility-Related Behavior in Zimbabwe. Population Research and Policy Review 2000; 19:255-282.

27. Upadhyay UD and Hindin MJ. Do Higher Status and More Autonomous Women Have Longer Birth Intervals? Results from Cebu, Philippines. Soc Sci Med 2005; 60(11):2641-2655.

28. Upadhyay UD and Karasek D. Women's Empowerment and Achievement of Desired Fertility in Sub-Saharan Africa. DHS Working Papers. 2010

29. Jejeebhoy SJ. Women's Education, Autonomy, and Reproductive Behaviour: Experience from Developing Countries. Oxford, England 1995: Clarendon Press.

30. Mason KO. The Impact of Women's Social Position on Fertility in Developing Countries. Sociological Forum 1987; 4:718-745.

31. NDHS. Nigeria Demographic and Health Surveys: Country Report, Calverton, MD, USA: Macro International, 2003.

32. Morgan SP, Stash S, Smith H Mason KO. Muslim and Non-Muslim Differences in Female Autonomy and Fertility: Evidence from Four Asian Countries. Population and Development Review 2012; 28(3):515-537

33. Creanga AA, Gillespie D, Karklins S, and Tsui AO. Low use of contraception among poor women in Africa: an equity issue. Bull World Health Organ. 2011 April 1; 89(4): 258-266.

34. Deepankar Basu dnd Robert De Jong. Son Targeting Fertility Behavior: Some Consequences and Determinants. Demography 2010; 47(2): 521-536. 